\title{
The Implementation of Balanced Scorecard as an Alternative Performance Measurenment at Samsat Mataram
}

\author{
Nungki Komaryati ${ }^{1}$, Akram $^{1}$, Basuki Prayitno ${ }^{3}$ \\ ${ }^{1,2,3}$ University Of Mataram
}

\begin{abstract}
:
This study aims to examine the possibility of applying balanced scorecard to SAMSAT Mataram Office. The assertion of the importance of a more comprehensive measurement method that traditional measurements we know so far is very difficult to measure the intangible assets. Therefore, a performance measurement system that is able to measure the value of the intangible assets is required to estimate and deliver an economic success of the organization. Implementation of a balanced scorecard supported by the correct reporting system will support the realization of good governance. This research uses qualitative approach with Case Study research strategy.

The result of the research shows that to increase the strategic role as public service provider institution with excellent service system and mechanism requires uniformity between performance measurement result with actual condition of office / institution performance or government organization. As a method of measuring the performance of the balanced scorecard framework is perceived to be relatively comprehensive, coherent, balanced and measurable compared to the measurement of AKIP performance in SAKIP, therefore the balance scorecard framework is then perceived as necessary for government agencies such as SAMSAT to be implemented in office performance measurement. Office performance measurement using the balance scorecard is not intended to replace the existing LAKIP framework within SAKIP, but rather an attempt to provide input within the AKIP framework by including key performance indicators that have not been considered in the SAKIP framework.
\end{abstract}

Keywords: performance achievement, balanced scorecard, public sector, SAMSAT Mataram City Office.

\section{Introduction}

Government organizations in the current era, both central and local governments are expected to be accountable, competitive, sociable, and focused on performance. Therefore it is considered to improve the success indicators of a government agency to better reflect the actual performance. In the module Socialization of Performance Accountability System Government Agencies LAN and BPKP (2000) explained that the success rate of a government agency should pay attention to all activities. The success rate should be measured not solely on the input of the agency program but rather emphasized on the output, processes, benefits, and impacts of the agency's programs for the welfare of the community. Through a performance measurement, the success of a government agency will be better seen from the agency's ability based on the resources it manages to achieve the results according to the plan that has been poured in strategic planning (LAN and BPKP, 2000).

The level of achievement of an organization's performance in the public sector will always be linked to the implementation of various principles of good governance or good governance. Implementation of the principles of "good government governance" in the implementation of government duties becomes a critical public demand in monitoring and evaluating the benefits and value derived from the services of government agencies. On the other hand, the measurement of success and failure of government agencies in carrying out their main tasks and functions is difficult to be done objectively because of the lack of performance measurement system that can inform objective and measurable success rate from the implementation of programs in a government institution. Along with its development, all organizations are required to compete 
to provide maximum service, not least government organizations. Similarly, government officials as public servants and government servants, are also required to be able to provide services to the community because it is already one of the functions that must be executed by the government who has the task of organizing the whole process of implementation of development in various sectors of life from the central level to regional level.

A public sector performance measurement system is a system that aims to help public managers assess the achievement of a strategy through financial and non-financial measures. Performance measurement system can be used as an organizational control tool, because performance measurement is strengthened by setting reward and punishment system. According to Madiasmo (2009), the measurement of public sector performance is conducted to fulfill three purposes: first, the measurement of public sector performance is intended to help improve government performance. Performance measures are intended to help governments focus on the goals and objectives of the work unit program. This will ultimately improve the efficiency and effectiveness of public sector organizations in the delivery of public services. Second, the sector performance measure Public is used for resource allocation and decision making. Third, measures of public sector performance are intended for the purpose of realizing public accountability and improving institutional communication (Madiasmo, 2009).

Badan Pengelolaan Pendapatan Daerah West Nusa Tenggara Provincial through SAMSAT Office should every effort to provide quality service and realize the targets of motor vehicle tax revenue, so as to establish a harmonious relationship between the service provider and the recipient of the service. In fact, public services provided by public sector agencies have not been optimal. This can be seen from the many complaints of people when taking care of the needs in government agencies. So far, the government measures the accountability performance of public sector institutions through a Government Accountability Performance Report (LAKIP) based on Government Regulation No. 8 of 2006 on Financial Reporting and Performance of Government Agencies. Broadly speaking, LAKIP contains a list of outcomes (outputs) of each agency, compared to targets contained in the organization's strategic plan. Measurements of LAKIP are aimed at assessing the use of government budget, in order to produce outputs that match the desired target. LAKIP has been quite well applied to government agencies but LAKIP is considered less able to describe the performance of agencies in a comprehensive manner.

To improve the performance of government / public sector organizations, a performance-based system is required. Good performance should have a reliable and qualified performance measurement system, so it is necessary to use performance measures that not only rely on financial aspects but also pay attention to non-financial aspects. The concept of Balance Scorecard is a measure of the performance of an organization that takes into account the financial and non-financial side, internal and external aspects, as well as considering the mass aspects of the past and the future aspects of the organization. There are 4 (four) basic perspectives in the Balance Scorecard, ie 1) financial / financial perspective; 2) customer perspective; 3) internal business process perspective; 4) learning and growth perspective. The four perspectives are interrelated in building the performance profile of an organization whose results are shown through a scorecard as the final result of an organization's performance measurement.

The use of the Balanced Scorecard concept in government organizations is believed to improve public sector accountability, improve public sector performance, improve service effectiveness, improve service quality and lower public service costs (Kaplan and Norton, 1993). By using the concept of Balance Scorecard, performance achievement is not only measured from the financial aspect such as the achievement of targets and realization, but also from the non-financial aspect, namely the satisfaction of the community. Therefore Balanced Scorecard is considered necessary to be applied to public sector organizations.

Performance indicators are needed so that in assessing organizational performance can be objective. The ideal indicators should be related to cost efficiency and service quality. Quality of service is related to fitness and objectivity, consistency, and public satisfaction. Community satisfaction in that context can be attributed to the lower complaint of the community (Madiasmo, 2009). According to Kepmenpan No Kep./25/M.PAN/2/2004 About the General Guidelines for Compilation of Public Satisfaction Index, consisting of: 1) service procedure, 2) service requirements, 3) clarity of service officers, 4) disciplinary officers, 5) responsibilities Service personnel, 6) the ability of service personnel, 7) speed of service, 8) justice to get service, 9) courtesy and friendliness of the officer, 10) fairness of service charge, 11) service cost certainty, 12) service schedule certainty, 13) And 14) service security. 
Badan Pengelolaan Pendapatan Daerah of West Nusa Tenggara Province has the main duty to assist the Governor in carrying out regional government affairs in the field of regional revenue based on the principle of autonomy. The main tasks undertaken by the Badan Pengelolaan Pendapatan Daerah of West Nusa Tenggara Province are among others the functions of formulating technical policies in the fields of income, planning of programs and activities in the field of income, administration of public affairs and public services in the field of income, coordinating and fostering tasks in revenue, control and evaluation of implementation Other tasks assigned by the Governor in accordance with their main duties and functions (LAKIP Dipenda NTB Province, 2016). The strategic aspect that influences the implementation of the main tasks and functions of the Regional Revenue Management Board of West Nusa Tenggara Province, among others influenced by the internal environment that became the main problem facing Bappenda West Nusa Tenggara Province and will affect the achievement of Bappenda performance is the quality of human resources is still low, The unavailability of valid potential data, service to the taxpayer community has not been optimal and the performance of bureaucracy is generally low. On the other hand, external environmental problems such as economic kisis, kamtibmas disruption, credibility of the government and public demand for service facilities also have an impact on the achievement of Bappenda performance in the present (LAKIP Dipenda NTB Province, 2016).

\section{Literature Review}

\subsection{Performance Measurement}

In every organization, performance is a key factor for realizing the vision and mission to be achieved. Performance is a description of the level of achievement of the implementation of an activity, program, policy in realizing the goals, objectives, mission and vision of the organization contained in the planning strategy of an organization (Nurhamidah, 2014). Prawirosentono (2001) said the performance is the result of work achieved by a person or group of people within an organization, in accordance with the authority and responsibility of each in an effort to achieve organizational goals. Performance can be known only if individuals or groups of individuals have predetermined success criteria. These success criteria are objectives or targets to be achieved. Without any goals or targets, the performance of a person or organization is unlikely to be known because there is no benchmark (Mahsun, 2006).

Basically, performance always leads to the potential work obtained from certain job functions or certain activities during a certain period of time, the work that can be achieved either individual or group within an organization in accordance with their respective responsibilities in order to achieve the goals of the organization concerned. Based on the understanding of the performance of some opinions of experts above, it can be interpreted that the performance of employees closely related to the results of a person's work within an organization, the results of the work can be related to quality, quantity, and timeliness. Employee performance is not only influenced by the ability and expertise in work, but also strongly influenced by the spirit of work. Therefore, performance is a real behavior that is displayed every person as work performance generated by employees in accordance with its role in the organization. By having reliable human resources and non human resources that support an organization can provide good results so that the quality and quantity of work generated also support the achievement of organizational goals.

Performance appraisals aim to motivate employees, in achieving organizational goals and in complying with predetermined standards of conduct, in order to produce desired outcomes and results. Performance appraisals are undertaken to suppress undue behavior and to stimulate and enforce desirable behaviors through timely feedback on performance results and rewards, whether intrinsic or extrinsic. According to Mahmudi (2013) performance measurements should at least include three important variables that must be considered: employees, behaviors, and outcomes, are inseparable and interdependent variables. The main purpose of performance appraisal is to motivate the personal in achieving the goals of the organization and in meeting the standards of behavior that have been set before, resulting in action and results desired by the organization (Mulyadi, 2001).

Implementation of performance indicators is the process of identification and classification of performance indicators through the system collection and pengelolahan data / information to determine the performance level of organizational programs. The organization's success in achieving its objectives can be determined by using the evaluation or assessment of the organization's activities under applicable rules, norms and ethics. Performance appraisal in a certain period of time is called the measurement of 
organizational performance, the results can be used as guidelines for improvement of organizational activities.

\subsection{Balanced Scorecard}

The definition of balanced scorecard according to Kaplan and Norton (1996) is a new framework for integrating the various measures derived from the company's strategy. Balanced scorecards not only use past financial performance measures, but also introduce future performance drivers. The performance drivers in question are the customer's perspective, internal business processes, and lessons learned and growth derived from the company's strategy translation process that is implemented explicitly and strictly into real goals and measures. The Balanced Scorecard gives corporate executives a comprehensive framework to translate the company's vision and strategy into a unified set of performance measures.

Balanced Scorecard, is a valuation method that is considered highly current and capable of being applied to public institutions and private institutions. Modern enterprise performance measurement by considering four perspectives (interconnected) which is the translation of strategy and goals desired by a company in the long term, which is then measured and monitored continuously (Mahsun, 2006). The Balanced Scorecard is a new approach to management, developed in the 1990s by Robert Kaplan (Harvard Business School) and David Norton (Renaissance Solution, Inc.). Recognition of some of the weaknesses and ambiguities of previous financial performance measurement approaches. The Balanced Scorecard presents a clear perspective as a company must measure in order to achieve a balance of financial perspective. The Balanced Scorecard stresses that all financial and nonfinancial measures should be part of the information system for workers at all levels of the company.

Balance Scorecard uses four measurements in its implementation, namely: 1) financial perspective; 2) customer perspective; 3) internal business process perspective; 4) learning and growth perspective. In the Balance Scorecard, a financial perspective is a measure of past performance, while customer perspective, internal business processes, and learning and growth encourage future performance (Kaplan and Norton, 1996).

\subsection{Balance Scorecard in Public Sector Performance Measurement}

According to Kaplan and Norton (2004), the Balanced Scorecard design implemented in public organizations is in order to realize the mission of the organization. The implementation of balanced scorecards supported by the correct reporting system will support the realization of good governance. Public Organization is an organization established with the aim of providing services to the community rather than profit (profit). This organization can be a government organization and other nonprofit organizations. Although public organizations are not for profit, the organization can measure its effectiveness and efficiency in providing services to the public. For that public organization can use Balanced Scorecard in its performance measurement.

Eagle (2004), delivered one of the reasons why Balanced Scorecard frameworks are important to implement to public organizations that are to respond to public demands that are stakeholders of the accountability and efficiency of public organizations. The current trend is that performance measurements have been made at all levels of government organizations. The main challenge is how to have a system or performance framework that can effectively share the priority allocations to the limited resources available in implementing those priorities and measuring the outcomes.

The government should bridge the gap between public expectations or social needs and the delivery of public services it provides. There are differences from the perspective of a balanced scorecard applied to profit-oriented business organizations (private sector) and public service oriented organizations (public sector) as shown in table 1 below:

Tabel 1. Differences Balance Scorecard Perspective on Private Sector and Public Sector

\begin{tabular}{|l|l|l|}
\hline \multicolumn{1}{|c|}{ Perspective } & \multicolumn{1}{|c|}{$\begin{array}{c}\text { Private/Business } \\
\text { Organization (Private } \\
\text { Sector) }\end{array}$} & $\begin{array}{c}\text { Government } \\
\text { Organization (Public } \\
\text { Sector) }\end{array}$ \\
\hline $\begin{array}{l}\text { Financial/Operational } \\
\text { Efficiency }\end{array}$ & $\begin{array}{l}\text { How do we see and give } \\
\text { value to shareholders? }\end{array}$ & $\begin{array}{l}\text { How do we see and value } \\
\text { people and / or } \\
\text { taxpayers? }\end{array}$ \\
\hline Customer & How do customers see and & How do people using \\
\hline
\end{tabular}




\begin{tabular}{|l|l|l|}
\hline & evaluate our performance? & $\begin{array}{l}\text { public services perceive } \\
\text { and evaluate our } \\
\text { performance? }\end{array}$ \\
\hline Learning and Growth & $\begin{array}{l}\text { Can we continue to improve } \\
\text { and creat value to our } \\
\text { customers shareholders, } \\
\text { employees and management } \\
\text { and organizations? }\end{array}$ & $\begin{array}{l}\text { Can we continue to } \\
\text { improve and create value } \\
\text { for the community / } \\
\text { taxpayers government } \\
\text { officials and officials, } \\
\text { and other stakeholders? }\end{array}$ \\
\hline Internal Process & $\begin{array}{l}\text { What should be featured } \\
\text { from word processes and } \\
\text { products? the development } \\
\text { programs implemented } \\
\text { provide the desired } \\
\text { outcomes? }\end{array}$ \\
\hline
\end{tabular}

Source : Gaspersz, 2002

From a number of different balanced scorecard perspectives, the application of the balanced scorecard in public sector organizations requires modification, but such modification does not necessarily have to be different from the balanced scorecard for business organizations. Balanced Scorecard is one of the performance measurement model of an organization, which not only emphasizes on how far the success of organization seen from financial aspect only, but more emphasized on balance (Balanced) between result (Result) that achieved with Enablers to reach (Nurhamidah, 2014). Balanced Scorecard is not only a measure of business or profit organization's performance but in the long run it can be used in public organization, both in financial (financial) and non-financial performance.

\section{Research Methods}

This research uses qualitative research type with case study approach. Qualitative research is a research that intends to understand the phenomenon in the object of research with the words as a whole and descriptive (Melong, 2006). Qualitative research method is a research method used to examine the condition of natural objects (Sugiyono, 2012). Cresswell (1998) argues that case studies are research models that emphasize a system's examination of a phenomenon in detail through the excavation of diverse sources of information.

In the implementation, this research will use purposive technique and is snowball sampling that is sampling technique of data source, which at first the number of little, long - long become big (Sugiyono, 2014: 219). This is done if a small number of data sources are not yet satisfactory, finding someone else that can be used as a data source is a way of doing snowball sampling technique so that informants are obtained to the point of saturation and no variation of answers from informants. Snowball sampling will be used on motor vehicle taxpayer informants.

Data collection is done by observation, interview and documentation. The researcher will do the validity of research data for the assurance of data accuracy. In qualitative research, the level of data validity is more emphasized on the data obtained, looking at it then the confidence data research results can be said to have a significant influence on The success of a study. To obtain valid data, this research will conduct validity test of data by conducting credibility test (validityas interbal) to data of research result in accordance with test procedure of data credibility in qualitative research. As a comparison to the data, then testing the validity of data is done by triangulation technique. In this research used qualitative data analysis with model.

\section{Result And Discussion}

\subsection{Performance Measurement Based On Lakip}

The concept of measuring the performance of SAMSAT Mataram with LAKIP approach is a concept of performance measurement that does not use a single indicator in assessing the performance of an organization. Performance measurement that only finances from the financial aspect alone is irrelevant in decision making because financial measures are considered not proactive to potential problems such as 
operational issues (non-financial indicators). The financial and non-financial dimensions are very important and are a supportive entity that can reflect the overall organizational performance (Srimindarti, 2004).

SAMSAT of Mataram City as one of the public sector organizations that provide services to the community. This organization is similar to the organization of government agencies as a whole that aims to provide optimal service and provide satisfaction for their service users. The indicator of the success of the organization of vehicle tax treatment services that have the same term characters with public sector organizations in general. The LAKIP approach can be used as a management tool to measure the performance of public sector organizations in general. The LAKIP approach can be used as a management tool to measure the performance of vehicle tax services (Imelda, 2005).

\subsection{Performance Measurement in Balance Scorecard Concept}

The Balanced Scorecard concept will be abbreviated BSC. BSC is an approach to management strategy developed by Drs.Robert Kaplan (Harvard Business School) and David Norton in the early 1990s. BSC comes from two words namely balanced and scorecards. Balanced means a balance between financial and non-financial performance, short-term performance and long-term performance, between internal performance and external performance. While the scorecard (scorecard) is a card used to record a person's performance score. The scorecard can also be used to plan the scores that a person is about to embody in the future. At first BSC was used to improve the executive performance measurement system. Initial use of executive performance is measured only in financial terms. It then develops into a wide range of four perspectives, which are then used to measure the performance of the organization in full.BSC is a management system mechanism that is able to translate organizational vision and strategy into real action in the field.

In its development BSC has helped many companies to successfully achieve its goals. BSC has several advantages that traditional management strategy systems lack. Traditional management strategies only measure the performance of the organization from the financial side only and more emphasize measurements on things that are tangible, but business development demands to change the view that intangible things also play a role in the progress of the organization. BSC responds to these needs through a contemporary strategy management system, consisting of four perspectives: financial, customer, internal business processes and learning and growth. The superiority of the BSC approach in strategic planning systems (Mulyadi, 2001, p.18) is capable of producing strategic plans, which have the following characteristics (1) comprehensive, (2) coherent, (3) balanced and (4) measurable.

There are 4 (four) basic perspectives in the Balance Scorecard, ie 1) financial / financial perspective; 2) customer perspective; 3 ) internal business process perspective; 4) learning and growth perspective. The four perspectives are interrelated in building the performance profile of an organization whose results are shown through a scorecard as the final result of an organization's performance measurement.

\subsubsection{Financial / Financial Perspective (Theme1)}

Financial Perspective according to Kaplan (Kaplan, 1996) at the time of the company's financial measurement, the first thing to do is to detect the existence of the industry it has. Kaplan classifies three stages of industrial development namely; growth, sustain, and harvest. From the stages of industrial development will require different strategies. In a financial perspective, there are three aspects of a company's strategy; (1) revenue growth and a combination of income owned by a business organization, (2) cost reduction and productivity improvement, (3) optimal asset use and investment strategy.

As noted earlier, the financial aspect remains an integral part of any organizational performance. Nevertheless there is a change of perspective in the financial perspective of the public sector. In public organizations, the financial perspective is more directed at how the organization improves its financial performance according to its own target effectively and efficiently.

Based on the results of the interviews, it was concluded that all informants explained that the performance implementation in the financial perspective provides benefits for management in SAMSAT Mataram City, and also becomes an evaluation of the activities of SAMSAT of Mataram City in order to measure the extent of the performance of the SAMSAT Office that has been implemented.

\subsubsection{Customer Perspective (Theme 2)}


The Customer Perspective, in this customer perspective, identifies how their customers and market segments have been chosen by the company to compete with their competitors. The segment they have chosen reflects the customer's existence as their source of income. In this perspective, measurements were performed with five main aspects (Kaplan, 1996: 67); that is :

1. the measurement of market share, the measurement of the size of the firm's market share reflects the proportion of business in a particular business area expressed in terms of money, customer amount, or unit volume sold over each unit of product sold.

2. customer retention, measurement can be done by knowing the percentage of business growth with the number of customers currently owned by the company.

3. customer acquisition, the measurement can be done through the percentage of the number of new customer additions and the ratio of total sales to the number of new customers available.

4. customer satisfaction, measurement to the level of customer satisfaction can be done with various techniques such as: survey by mail (post), telephone interview, or personal interview.

5. customer profitability, measurement to customer profitability can be done by using Activity BasedCosting (ABC) technique.

Based on the results of the interviews, it was concluded that all informants explained that the implementation of performance in the perspective of the customer provides benefits for management in SAMSAT of Mataram City, and also become an evaluation of the service that has been implemented.

\subsubsection{Internal Business Process Perspective (Theme 3)}

The Internal Business Process Perspective, in this perspective, the public sector takes measurements of all activities performed by the public sector / companies both managers and employees to create a product that can provide certain satisfaction for the customer as well as the shareholders. In this case the company focuses on three main business processes namely: process innovation, operation process, post sales process.

Internal business process perspective on business organization with public organization is basically the same that is to build organizational superiority through continuous improvement of internal process of organization (Mahmudi, 2005). In the internal business process, the organization identifies key processes that need to be properly managed in order to build excellence for the organization.

Based on the results of the above interviews, it was concluded that all informants explained that the implementation of performance in the internal business process perspective provides benefits for management in SAMSAT of Mataram City, and also becomes an evaluation of the process.

\subsubsection{Learning and Growth Perspective (Theme 4)}

The Growth and Learning Perspective, the last perspective in the Balanced Scorecard is the growth and learning perspective. Kaplan (Kaplan, 1996) reveals how important a business organization is to continuously pay attention to its employees, monitor employee welfare and improve employee knowledge because with increasing levels of employee knowledge will improve also the ability of employees to participate in achieving the results of the above three perspectives and company goals.

Customer satisfaction, as previously disclosed, is a top priority in the concept of Balance Scorecard for the public sector because customer satisfaction is a leverage for the achievement of the main objective of public sector organizations, namely the increasing of welfare society. Customer satisfaction is closely related to how society, as the largest stakeholder, views the organization's performance over the years.

The learning and growth perspective identifies the parameters of inconvenience for public organizations. In public organizations, learning and growth perspectives are directed at increasing organizational values in the eyes of its customers and stakeholders. Growth and learning will affect the customer's perspective and internal business process perspective by increasing the organization's strategic objectives.

Based on the results of the interviews, it was concluded that all informants explained that the implementation of performance in learning and growth perspective gave benefit to management in SAMSAT of Mataram City, and also became an evaluation of the activities of SAMSAT Mataram City in order to measure the extent of performance of SAMSAT Office that has been held.

\subsection{Comparison between LAKIP and Balanced Scorecard (Theme 5)}


In the early days of implementing the Balanced Scorecard it was not a priority, nor was it noticed. Perhaps there are too many tools to measure employee performance so the impression of using Balanced Scorecard is useless. According to Mardiasmo (2009), it is necessary to measure the performance of the public sector to fulfill three purposes: 1) the measurement of public sector performance is intended to help improve the performance of the government. Performance measures are intended to help governments focus on the goals and objectives of the work unit program. This will ultimately improve the efficiency and effectiveness of public sector organizations in the delivery of public services; 2) measures of public sector performance used for resource allocation and decision making; 3) measures of public sector performance aimed at realizing public accountability and improving institutional communications.

Public organization is an organization established with the aim of providing services to the community rather than profit (profit). This organization can be a government organization and other nonprofit organizations. Although public organizations are not for profit, the organization can measure its effectiveness and efficiency in providing services to the public. For that public organization can use balanced scorecard in its performance measurement.

Eagle (2004), conveys one of the reasons why BSC frameworks are important to implement to public orgaizations that are to respond to public demands that are stakeholders of accountability and efficiency of public organizations. The current trend is that performance measurements have been made at all levels of government organizations. The main challenge is how to have a system or performance framework that can effectively share the priority allocations to the limited resources available in implementing those priorities and measuring the results.

Based on the results of the interviews, it was concluded that all informants explained that the performance measurement by using LAKIP is only a measurement of technical performance that is based on the budget, does not pay attention to non technical non financial as a trigger of performance. In Balance Scorecard has been paying attention to performance measurement such as: stakeholders' satisfaction level, employee satisfaction level, number of employees attending the training, and the use of quality information to support the services provided, and others.

\section{Conclusions, Implications And Limitations}

\subsection{Conclusion}

Based on the data and information that has been clustered into 5 (five) themes that describe in full and clear about how the possibility of application of balance scorecard at SAMSAT Office of Mataram City, concluded that:

1. Performance Measurement of SAMSAT of Mataram City conducted by internal organization and society served is evaluated on the performance of service of motor vehicle tax to society, it is expected that the management of SAMSAT service in Mataram can utilize the function in order to create performance improvement.

2. Limitations on the number and capacity of human resources to be the cause of less performance maximal implementation.

3. The performance should be carried out in the form of coordination with all parties related to the effort to get input from all parties not limited to the community such as NGO or stakeholder in government.

\subsection{Implications}

This research can provide theoretical implications for Sector Accounting research in terms of applying a balanced scorecard to public sector organizations. The results of this study conclude that improving performance measurement by applying the scorecard balance framework that has been designed will provide the direction and focus of work to be implemented by the organization in accordance with the vision, mission, objectives, and strategies that have been set previously. Performance measurement with a balanced scorecard framework will provide data and information about the condition of the organization more comprehensively and accurately.

The results of this research have implications on several policies: first, NTB Provincial Regulation No. 7 of 2008 on the formation, position, task, organizational structure and working arrangement of regional services. Second, improve / increase NTB Governor's Regulation Number 21 Year 2008 about the details of duties, functions, and work procedures of regional offices of West Nusa Tenggara Province.

Performance measurement with a balanced scorecard framework will provide data and information about the organization's conditions more comprehensively and accurately. Comprehensive and accurate data 
and information obtained from performance measurement is intended to assist the management of Bappenda NTB provincial leadership in taking further policy on samsat services tailored to the development of political, social, economic, and emerging technologies.

\subsection{Limitations}

In this study the authors have evidence of shortcomings and weaknesses that must still be given, in terms of. Therefore, in future studies, these shortcomings can be reduced so as to provide better results.

\section{References}

[1] Creswell, J.W. 2010. Research Design. Pendekatan Kualitatif, Kuantitatif dan Mixed. Yogyakarta: Pustaka Pelajar.

[2] Eagle, Kim., Cooke, Theodore C., Rossi, Terri SC, 2004. Translating Strategy Into Result (Public Sector Applications of the Balanced Scorecard). Government Finance Review. Vol 20,5, pg 16.

[3] Gaspersz, Vincent. 2002. Sistem Manajemen Kinerja Terintegrasi Balance Scorecard dengan Six Sigma untuk Organisasi Bisnis dan Pemerintah. Jakarta : Gramedia Pustaka Utama.

[4] Imelda, R.H.N. 2005. Implementasi Balance Scorecard pada Organisasi Publik. Jurnal Akuntansi dan Keuangan. Vol 6 Nomor 2.

[5] Kaplan, Robert S. dan David P. Norton. 1996. The Balanced Scorecard: Translating Strategy Into Action. Boston: Harvard Business School Press.

[6] LAN \& BPKP. 2000. Modul Sosialisasi Sistem Akuntabilitas Kinerja Instansi Pemerintah. Cetakan Pertama. Lembaga Administrasi Negara. Jakarta.

[7] LAKIP Dinas Pendapatan Provinsi NTB Tahun 2016.

[8] Mahmudi. 2005. Manajemen Kinerja Sektor Publik. UPP STIM YKPN.

[9] Mahsun, Mohamad. 2006. Pengukuran Kinerja Sektor Publik. Yogyakarta: BPFE.

[10] Madiasmo, 2009. Akuntansi Sektor Publik. Yogyakarta: Penerbit Andi.

[11] Moleong. Lexy J. 2001. Metodologi Penelitian Kualitatif. Bandung : PT Remaja Rosdakarya.

[12] Mulyadi. 2001. Balanced Scorecard Alat Manajemen Kontemporer untuk Pelipat Ganda Kinerja Keuangan Perusahaan Penerbit Salemba Empat. Universitas Gajah Mada.

[13] Nurhamidah. 2014. Pengaruh Penerapan Balance Scorecard terhadap Kinerja Pegawai pada Dinas Kelautan dan Perikanan Provinsi Sumatera Utara. Tesis. Universitas Sumatera Utara.

[14] Prawirosentono Suryadi. 2001. Model Manajemen Sumber Daya Manusia Indonesia, Asia dan Timur Jauh. Jakarta : Bumi Aksara.

[15] Srimindarti, Ceacilia. 2004. Balance Scorecard sebagai Alternatif untuk Mengukur Kinerja. Fokus Ekonomi. Volume 3 Nomor 1. April 2004.

[16] Sugiyono. 2012. Metode Penelitian Kuantitatif Kualitatif dan R\&D. Bandung: Penerbit Alfabeta.

[17] 2014, Metode Penelitian Kuantitatif, Kualitatif dan $R \&$ D. Bandung: Alfabeta. 